\title{
Trophic partitioning between abundant demersal sharks coexisting in the North Aegean Sea
}

\begin{tabular}{|c|c|}
\hline Journal: & Journal of the Marine Biological Association of the United Kingdom \\
\hline Manuscript ID & JMBA-04-18-OA-0109.R5 \\
\hline Manuscript Type: & Original Article \\
\hline $\begin{array}{r}\text { Date Submitted by the } \\
\text { Author: }\end{array}$ & 18-Jan-2019 \\
\hline Complete List of Authors: & $\begin{array}{l}\text { yemisken, emre; istanbul university, biology } \\
\text { Navarro, Joan; Estación Biológica de Doñana (EBD-CSIC), } \\
\text { Forero, Manuela; Estacion Biologica de Donana CSIC } \\
\text { Megalofonou, Persefoni ; University of Athens, Biology } \\
\text { Eryılmaz, Lütfiye }\end{array}$ \\
\hline Keywords: & $\begin{array}{l}\text { Feeding Ecology, Demersal Sharks, Aegean Sea, Gokceada Island, } \\
\text { Trophic position, stable isotopes }\end{array}$ \\
\hline Abstract: & $\begin{array}{l}\text { Here, we examined the feeding ecology (diet, trophic width and trophic } \\
\text { position) of five shark species (Mustelus mustelus Linnaeus, } 1758, \\
\text { Galeus melastomus Rafinesque, 1810, Scyliorhinus canicula Linnaeus, } \\
1758 \text {, Scyliorhinus stellaris Linnaeus, } 1758 \text {, Squalus blainville, Risso, } \\
1826 \text { ) coexisting in northeastern Aegean Sea (around Gökçeda Island) } \\
\text { by combining stomach content and stable isotope analyses. The results } \\
\text { indicated clear differences according to diets between five sharks. } \\
\text { Although, cephalopods mainly found in diet of S. stellaris and M. } \\
\text { mustelus, stomachs of G. melastomus, S. canicula and S. blainville } \\
\text { included fishes. } \\
\text { S. blainville has shown highest trophic position in stable isotope analysis } \\
\text { (TPsia=4.89) around Gökçeada Island. It is followed by G. melastomus } \\
\text { (TPsia= 4.57). Direct isotopic values (both stable nitrogen and carbon) } \\
\text { and isotopic niche width based on the Standard Ellipse Area (SEA) clearly } \\
\text { differed among the five shark species. In particular, S. blainville was } \\
\text { isotopically segregated from the rest of shark species, M. mustelus, S. } \\
\text { canicula, S. stellaris and G. melastomus, showing a narrow isotopic } \\
\text { trophic niche and higher trophic level. In the opposite, M. mustelus had } \\
\text { the widest trophic niche fo the five studies species. The niche width of S. } \\
\text { stellaris was lower than M. mustelus and S. canicula but higher than S. } \\
\text { blainville and G. melastomus. SEA showed that G. melastomus has } \\
\text { specialized feeding strategy in the area. There is no overlap between S. } \\
\text { canicula and S. stellaris in trophic width. }\end{array}$ \\
\hline
\end{tabular}

\section{SCHOLARONE" Manuscripts}


1 Trophic partitioning between abundant demersal sharks coexisting in the North

\section{Aegean Sea}

3

4 EMRE YEMISKEN ${ }^{1}$, JOAN NAVARRO $^{2}$, MANUELA FORERO $^{3}$, PERSEFONI $^{2}$

$5 \quad$ MEGALOFONOU $^{3}$, LUTFIYE ERYILMAZ $^{1}$

6

$7{ }^{1}$ Department of Biology, Section of Hydrobiology, Faculty of Science, Istanbul University,

8 Turkey, ${ }^{2}$ Institut de Ciencies del Mar - CSIC, Passeig Maritim de la Barceloneta, 37-49 08003

9 Barcelona, Spain, ${ }^{3}$ Department of Conservation Biology, Estacion Biologica de Donana (EBD-

CSIC), Avda. Americo Vespucio s/n, Sevilla 41092, Spain, ${ }^{4}$ Department of Biology, Section of 


\section{ABSTRACT}

We examined the feeding ecology (diet, trophic width and trophic position) of five demersal shark species (Mustelus mustelus Linnaeus, 1758, Galeus melastomus Rafinesque, 1810, Scyliorhinus canicula Linnaeus, 1758, Scyliorhinus stellaris Linnaeus, 1758, Squalus blainville, Risso, 1826) coexisting in northeastern Aegean Sea (around Gökçeda Island) by combining stomach content and stable isotope analyses. The results indicate clear differences in diet between the five sharks. Cephalopods were mainly found in diet of S. stellaris and $M$. Mustelus and stomachs of G. melastomus, S. canicula and S. blainville included fish.

S. blainville showed the highest trophic position in respect of stable isotope analysis $\left(\mathrm{TP}_{\mathrm{sia}}=4.89\right)$ around Gökçeada Island. It was followed by G. melastomus $\left(\mathrm{TP}_{\mathrm{sia}}=4.57\right)$. Direct isotopic values (both stable nitrogen and carbon) and isotopic niche width based on the Standard Ellipse Area (SEA) clearly differed among the five shark species. In particular, S. blainville was isotopically segregated from the rest of shark species, M. mustelus, S. canicula, S. stellaris and G. melastomus, showing a narrow isotopic trophic niche and higher trophic level. In contrast, M. mustelus had the widest trophic niche of the five species studied. The niche width of S. stellaris was lower than M. mustelus and S. canicula but higher than S. blainville and G. melastomus. SEA showed that G. melastomus has a specialized feeding strategy in the area. There is no overlap between $S$. canicula and $S$. stellaris in trophic width. 


\section{INTRODUCTION}

Knowing the trophic ecology of marine predators is pivotal to understanding their trophic relationships and functional roles in ecosystems (e.g. Abdul-Malak et al. 2011; Barría et al., 2015; Navia et al., 2017). Among marine predators, sharks are considered important predators within marine ecosystems, although differences in their main trophic habits exist (Cortés, 1999; Barría et al., 2015; Navia et al., 2017). They frequently play a predatory role and their removal could affect the function of marine ecosystems (Baum \& Worm, 2009). During the last few decades, elasmobranchs have become the focus of ecological studies (e.g. Ferretti et al., 2013; Dulvy et al., 2014; Navia et al., 2017). However, few studies have focused on interactions among sympatric elasmobranchs, an essential element to understanding how ecologically similar elasmobranchs coexist in the same habitats (e.g. Albo-Puigserver et al., 2015; Barría et al., 2015; Navia et al., 2017). Based on the principle of competitive exclusion, predators occupying similar trophic niches are expected to lead to ecological divergence or exclusion (Pianka, 2000). However, in some cases, closely related elasmobranchs coexist in the same communities and partitioning of food resources has been proposed as one of the main mechanisms to explain their coexistence (e.g. White et al., 2004 Vaudo \& Heithaus, 2011; Heithaus et al., 2013; Albo-Puigserver et al., 2015).

In comparison with other Mediterranean areas, research focusing on sharks inhabiting the North Aegean Sea (eastern Mediterranean Sea) is very limited, even though these waters host around 28 shark species, including threatened and rare species (Kabasakal, 2002a,Yığın et al., 2015). Although there are some studies in the Aegean Sea reporting the diet of several species of sharks based on stomach contents (Kabasakal, 2002b, Çakır et al., 2006; Filiz \& Taşkavak, 2006; Filiz, 2009; Karachle \& Stergiou, 2010), few studies have investigated different species simultaneously in the North Aegean Sea. 
The diet of marine organisms has been traditionally studied through stomach content analysis (SCA) (Cortés, 1997, 1999; Ellis et al., 1996). Although stomach content analysis allows high levels of taxonomic resolution, some marine predators such as sharks often show a high frequency of empty stomachs, and the prey items present in the stomachs are often skewed towards those that are more difficult to digest. Moreover, this methodology requires a large number of individuals, which can be difficult to obtain for elasmobranchs (Cortés, 1999, Stergiou \& Karpouzi, 2001). Stable isotope analysis (SIA) of nitrogen $\left(\delta^{15} \mathrm{~N}\right)$ and carbon $\left(\delta^{13} \mathrm{C}\right)$ has been used as a complementary tool to SCA to examine the trophic ecology of marine predators including sharks. SIA are useful to describe and understand the trophic position of species and explain trophic relationships in marine food webs (De Niro \& Epstein, 1981; Peterson \& Fry, 1987; Fry, 2007). $\delta^{13} \mathrm{C}$ values can be useful to assess sources of primary production in marine systems, whereas $\delta^{15} \mathrm{~N}$ values are used for prediction of relative trophic level.

In this study, we examined feeding ecology (diet habits, trophic width and trophic position) of five sharks - blackmouth catshark Galeus melastomus, common smoothhound Mustelus mustelus, longnose spurdog Squalus blainville, small-spotted catshark Scyliorhinus canicula and nursehound S. stellaris- coexisting in the North Aegean Sea by using stable isotopic and stomach content techniques. Based on previous knowledge of the diet of these shark species and taking into account their coexistance, we expected some degree of trophic partitioning between the species (Kabasakal, 2002b; Karachle \& Stergiou, 2010; Bradai et al., 2012; Yı̆̆ın et al., 2015). Our study provides new insights into the ecological role of these five species within the demersal community, updating our knowledge of how these relatively abundant demersal sharks exploit available resources. 


\section{MATERIALS AND METHODS}

\section{Study area and sampling procedures}

The North Aegean Sea is one of the most productive areas in the Eastern Mediterranean Sea. Nutrient rich Black Sea waters play an important role in sustaining high biological productivity and fish stocks in the North Aegean (Stergiou et al.,1997; Pethiakis et al., 2014). Some parts of the area have been identified as important habitats for seagrass (Posidonia oceanica) meadows, especially in Saros Bay and the northern part of Gökçeada Island for Turkish waters and there are also some spawning and nursery grounds for small pelagic and demersal fish (Machias et al., 2007; Öztürk, 2009; Güreşen et al., 2015).

A total of twenty-six blackmouth catsharks, eight smoothhounds, twelve longnose spurdogs, sixty-four small-spotted catsharks, and fourteen nursehounds were collected between September 2014 and April 2016 at a depth ranging from 33 to $450 \mathrm{~m}$, by commercial trawl vessels around Gökçeada Island (North Aegean Sea; Figure 1). All sharks were accidentally captured as by-catch of fishing operations. Individuals were taken to the laboratory in a freezer where body size (Total length; TL, to the nearest $\mathrm{mm}$ ) and weight (nearest g) were recorded.

\section{Stomach Content Analysis}

All prey items presented in the stomach of each individual were identified at a functional prey level (Annelid, Crustacea, Cephalopods and Teleosts) and species level when it was possible. Most prey were obtained as digested material in the stomach. Weight (W\%) and frequency of occurrence $(\mathrm{F} \%)$ of prey items were calculated (Cortes, 1997). The vacuity index (v; the percentage of empty stomachs) and the percentage of fullness of stomachs (Fullness \%) were also calculated (Hyslop, 1980; Amudsen et al., 1996). Based on the dietary composition (expressed as $\mathrm{W} \%$ ), the mean fractional trophic level of the species was estimated using the 
corresponding routine TrophLab and the equation: $\mathrm{TP}_{\text {stomach }}=1+\mathrm{j}=1 \sum \mathrm{GDCj} * \mathrm{TP} \mathrm{j}$, where $\mathrm{DCj}$ is the proportion of the prey category $\mathrm{j}$ that makes up for the species diet, TPj is the trophic level of the prey category $\mathrm{j}$ and $\mathrm{G}$ is the total number of prey categories recorded in the species (Pauly et al., 2000).

\section{Stable Isotope Analysis}

We collected a small portion of muscle from the pectoral fins of each shark species. Before stable isotope analysis, we extracted lipid from muscle samples using a chloroform-methanol solution (Kim \& Koch, 2012; Kim et al. 2012). Samples were subsequently freeze-dried and powdered and 0.28 to $0.4 \mathrm{mg}$ of each sample was packed into tin capsules. Isotopic analyses were performed at the Stable Isotopes Laboratory at the Estación Biológica de Doñana CSIC (Seville, Spain). Samples were combusted at $1020^{\circ} \mathrm{C}$ using a continuous flow isotope ratio mass spectrometry system (Thermo Electron) by means of a Flash HT Plus elemental analyser coupled to a Delta-V Advantage isotope ratio mass spectrometer. Stable isotope ratios were expressed in the standard $\delta$-notation (\%o) relative to Vienna Pee Dee Belemnite $\left(\delta^{13} \mathrm{C}\right)$ and atmospheric $\mathrm{N}\left(\delta^{15} \mathrm{~N}\right)$. Based on laboratory standards, the measurement error was \pm 0.1 and \pm 0.3 for $\delta^{13} \mathrm{C}$ and $\delta^{15} \mathrm{~N}$, respectively.

\section{Statistical analysis}

As a measure of trophic width, Bayesian isotopic ellipse area (SEA) was calculated for each species by derivation of the stable isotope values (Jackson et al., 2011). This metric represents a measure of the total amount of the isotopic niche exploited by a particular predator and is thus a proxy for the extent of trophic diversity (or trophic width) exploited by the species (high values of isotopic standard ellipse areas indicate high trophic width). This metric uses multivariate ellipse-based Bayesian metrics. Bayesian inference techniques allow for robust 
statistical comparisons between data sets with different sample sizes. Isotopic standard ellipse areas were calculated using the routine Stable Isotope Bayesian Ellipses incorporated in the SIAR library (SIBER, Jackson et al., 2011, Shiffman et al. 2012). Also, C and N isotope values according to shark species were tested by using non parametric varience analysis (KruskalWallis and U Mann Whitney) in Statistica software.

\section{Trophic Position}

The trophic position (TP) of each species was estimated by using isotopic values $\left(\mathrm{TP}_{\mathrm{SIA}}\right)$. $\mathrm{TP}_{\mathrm{SIA}}$ was performed according to Zanden and Rasmussen (2001): $\mathrm{TP}_{\text {consumer }}=\mathrm{TP}_{\text {basal }}+\left(\delta 15 \mathrm{~N}_{\text {consumer }}\right.$ $\left.-\delta^{15} \mathrm{~N}_{\text {basal }}\right) / \Delta \delta^{15} \mathrm{~N}$, where $\delta^{15} \mathrm{~N}_{\text {consumer }}$ is the value for each shark species, $\delta^{15} \mathrm{~N}_{\text {basal }}$ is that of the crab Monodaeus couchii (7.1\%) sampled from the east Mediterranean Sea. We used 1.95 for $\Delta^{15} \mathrm{~N}$ values (Hussey et al., 2010), defined as the trophic enrichment factor between organism and diet. Trophic position was compared with total body length in each species by using Kruskal Wallis test in Statistica software.

\section{RESULTS}

\section{Stomach content}

A total of 124 stomachs were analysed belonging to five shark species. We found that 117 of these individuals had prey in their stomachs (Table 1). Taking into consideration all specimens, stomach content results indicated that the diet of lesser small-spotted catsharks, longnose spurdogs and blackmouth catsharks were composed mainly of teleosts. Cephalapods were mostly found in the diet of nursehounds, while Crustaceans and Cephalopods were predominantly found in stomachs of common smoothhounds. Annelids were only found in the stomachs of small-spotted catsharks. The crab Liocarcinus depurator was found in stomach of 
the common smoothhound. The Cephalopods Illex coidetti and Loligo vulgaris were identified in diets of the longnose spurdog and the blackmouth catshark. Parapenaeus longirostris and Munida intermedia were identified as Crustacean prey in the diet of the small-spotted catshark and the Teleost, Engraulis encrasicolus was found in the stomachs of the longnose spurdog.

\section{Stable isotopic analysis results}

$\delta^{13} \mathrm{C}$ and $\delta^{15} \mathrm{~N}$ values differed between the five shark species (Kruskal-Wallis tests; $\delta^{13} \mathrm{C}$, $\left.\chi^{2}=14.87, \mathrm{p}=0.005 ; \delta^{15} \mathrm{~N}, \chi^{2}=24.11, \mathrm{p}<0.0001\right)$. The U-Mann Whitney pairwise test indicated that for $\delta^{13} \mathrm{C}$, the small-spotted catshark showed the highest values followed by the longnose spurdog, the blackmouth catshark, the nursehound and the common smoothhound (Figure 2, Table 2). For $\delta^{15} \mathrm{~N}$ values, nursehounds showed the lowest values followed by the small-spotted catshark and the common smoothhound, the blackmouth catshark and the longnose spurdog (Figure 2, Table 2). Similar to the $\delta^{15} \mathrm{~N}$ values, the longnose spurdog showed the highest trophic position, followed by the blackmouth catshark, the common smoothhound, the small-spotted catshark and the nursehound (Table 1).

The isotopic Bayesian areas $\left(\mathrm{SEA}_{\mathrm{C}}\right)$ showed a clear segregation between the five sharks (Figure 2). In particular, the blackmouth catshark $(\mathrm{SEAc}=0.32)$ and the longnose spurdog $(\mathrm{SEAc}=0.53)$ showed the lowest values, followed by the nursehound $(\mathrm{SEAc}=1.33)$, the smallspotted catshark $(\mathrm{SEAc}=1.38)$ and, with the highest values, the common smoothhound (SEAc $=2.36$ ) (Figure 2).

\section{Trophic Level}

The trophic levels estimated using stomach content $\left(\mathrm{TL}_{\text {stomach}}\right.$; Table 1) and isotopic values $\left(\mathrm{TP}_{\mathrm{SIA}}\right.$; Table 2) were similar for the blackmouth catshark and the common smoothhound (Tables $1 \& 2$ ). For the small-spotted catshark, the nursehound and the longnose spurdog, TL 
was different between $\mathrm{TP}_{\text {stomach }}$ and $\mathrm{TP}_{\mathrm{SIA}}$, the latter being lower (Tables 1-2). Based on $\mathrm{TP}_{\mathrm{SIA}}$, the highest and the lowest values were showed in the longnose spurdog and the nursehound, respectively (Table 2). Based on $\mathrm{TP}_{\text {stomach }}$, the highest and the lowest values were found in the blackmouth catshark and the nursehound, respectively (Table 2). Trophic position was significantly different according to body length in each species $(p=0,000017 ; p<0.005)$.

\section{DISCUSSION}

In the present study, the trophic habits of five demersal sharks inhabiting the North Aegean Sea (east Mediterranean Sea) were studied by combining stomach content and stable isotopic analyses. These species are the most abundant shark species in trawl fisheries of the North Aegean Sea (unpublished data). Stomach contents provided a snapshot of the diet of each species, and muscle isotopic values identified the trophic habits integrated over the longer term (Peterson \& Fry, 1987; Jenning et al. 1997; Kim \& Koch, 2012; Navarro et al., 2014). Based on the results of both stable isotopes and stomach contents, we found clear differences in the trophic habits (diet composition, trophic niche and trophic level) among these five demersal sharks.

Overall, the results show, the five shark species displayed opportunistic feeding behaviour with priorities for different prey, mainly composed of cephalopods, fishes and crustaceans (Çakır et al., 2006; Filiz \& Taşkavak, 2006; Jarda et al., 2007; Filiz, 2009; Karachle \& Stergiou, 2010). Polychaetes and echinoderms have been included only as minor importance in their food (Filiz \& Taşkavak, 2006; Bradai et al., 2012). Cephalopods are a major prey for the longnose spurdog, the small-spotted catshark and the blackmouth catshark (Kabasakal, 2002a, Karachle \& Stergiou, 2010; Bradai et al., 2012). The nursehound catshark feeds in a smilar way to the small spotted catshark (Compagno, 1984; Eronat, 2012) (Table 3). In our study, we found that nursehound catsharks feed mainly on Cephalapods, although Teleosts were preferred by small- 
spotted catsharks. Differences observed in the stomach content between the two species in this study were confirmed with SIA results for both species. These may be explained by the resources available in their habitats.

A comparison between previous studies and the current is shown some differences because of regional variations in the Mediterranean Sea. According to Ozutemiz et al. (2009), crustaceans were found to dominate the stomach contents of the blackmouth catshark in the central Aegean Sea, whereas in this study stomach contents were dominated by fish. In contrast, blackmouth catsharks were defined as specialist feeders in the west Mediterreanean Sea and a high overlap in diets was recognized for the sympatric species, blackmouth catsharks and smallspotted catsharks (Valls et al., 2011). They predominantly consumed crustaceans in the area studied. Albo-Puigserver et al. (2015) noted that blackmouth catsharks preferred Cephalopods and shrimp in the Gulf of Lions (western Mediterranean Sea). Differences between these results may be due to variations in the proportion of prey in different seasons and the variation in body sizes of individuals (Olaso et al., 1998; Albo-Puigserver et al., 2015). Although, some studies indicate that the blackmouth catshark has a generalist and opportunistic feeding strategy, there were some results there it was characterized as having a specialist feeding strategy in the Mediterranean Sea (Olaso et al., 1998; Bozzano et al., 2001; Fanelli et al., 2009; Ozutemiz et al., 2009; Valls et al., 2011; Anastasopoulou et al., 2013). This has been explained that when food availability and prey diversity are high, it probably prefers specific prey. In our study we have shown blackmouth catsharks having a specialized feeding strategy with narrow nich width.

As expected from the stomach content results, interspecific differences in the isotopic values and trophic levels were found. In particular, the longnose spurdog was isotopically segregated from the other species, showing a lower isotopic trophic width and higher trophic level. The trophic width estimated with SEAs indicated, G. melastomus and S. blainville have specialized 
232 feeding behaviours, although the common smoothound and the small-spotted catshark showed a generalized feeding strategy.

Our TL estimates from stable isotopes differed to those of other studies available in the literature. For the blackmouth catshark the trophic level estimated by stable isotopes was higher than the trophic level estimated from other areas of Mediterranean Sea (Ozutemiz et al., 2009; Alba-Puigserver et al., 2015). TP of small-spotted catsharks was similar to the western Mediterranean Sea (Barria et al., 2017), while it was lower than the trophic level estimated by stomach content from the North Aegean Sea according to (Karachle \& Stergiou, 2010).

Differences between $\mathrm{TP}_{\text {sia }}$ and $\mathrm{TP}_{\text {stomach }}$ are to be expected considering that the estimated trophic levels from isotopic data are sensitive to the basic assumption of which basal sources are used (Olin et al., 2013). However, differences observed in the trophic position between the two methods in this study might be explained by long-term and short-term prey preference differences of shark species in the region. Besides, discrepancies between methodologies $\left(\mathrm{TP}_{\text {sia }}\right.$ and $\left.\mathrm{TP}_{\text {stomach }}\right)$ have revealed the need for caution when values of trophic levels are compared (Albo-Puigserver et al., 2015). Also, we found differences in the TPs between species especially for longnose spurdogs - using both the stomach analysis and stable isotope analysis approaches, due to the low number of stomach samples.

Several studies concluded that trophic partitioning in same habitats reduced the potential for competition for resources (Macpherson, 1981; White et al., 2004 Voudo \& Heithaus, 2011). Although obtained five shark species feed onwith same groups of prey, they probably prefer different prey species in the area. The isotopic niche space (SEAc) results indicated, smallspotted catshark not to overlap any other sharks. However, common smoothhound shark overlapped with nursehound and blackmouth catshark, suggesting niche partitioning between distributes the shelf slope. Both two species distribute in different depth ranges in general. This 
means that the common smoothhound shark might showed widely distribution in according to different depth zone. On the middle slope, it is considered a habitat overlap among blackmouth catshark, common smoothhound shark, longnose spurdog and small-spotted catshark. Their distributions show similar depth ranges (Kabasakal 2002a). Diet composition of these species could reflect the specific features of the different habitat distribution, because of the differences in food availability in the different areas. Kousteni et al. (2017a), described a similar situation for small-spotted catsharks in the Aegean Sea. The stable isotope results could indicate the relationship between feeding habits and species distribution overlap. But, we need more data in order to evaluated overlapping situation between species.

In conclusion, this study presents new information regarding the feeding ecology of five relatively abundant demersal sharks in the north Aegean Sea. They exploit different trophic resources, segregating their trophic niche. The results indicate differences in diet between species, showing a clear feeding preference for teleosts in the case of the blackmouth catshark, and the longnose spurdog and a diet composed of cephalopods in the case of the common smoothhound and the nursehound. Crustaceans with teleosts and cephalopods were preferred by the small-spotted catshark. Different bathymetric distribution and habitat richness could influence prey preferences not only between species but also among population of the same species. precisely. These results provide new insights into the mechanisms supporting the coexistence of demersal predators and their ecological role. These results can be used by managers to conduct appropriate assessments and inform conservation strategies for these species.

\section{ACKNOWLEDGMENTS}


We thank Onur Gönüal and Mert Kesiktaş for their help during the sampling and laboratory 283 process and to Susana Carrasco for her help during the stable isotope analysis. JN was supported 284

by Spanish National Program Ramón y Cajal. This study was partially funded by Istanbul University (project no: 52069) and TUBITAK 2214A (phd. student international scholarships programme).

\section{REFERENCES}

Abdul Malak D., Livingstone S. R., Pollard D., Polidoro,B. A., Cuttelod A., Bariche, M., Bilecenoglu M., Carpenter K. E., Collette B. B., Francour P., Goren M., Kara M. H., Enric M., Papaconstantinou C. and Tunesi L. (2011) Overview of the Conservation Status of the Marine Fishes of the Mediterranean Sea. International Union for Conservation of Nature (IUCN), Gland, Switzerland and Malaga, Spain, ISBN: 978-2-8317-1307-6

Albo-Puigserver M., Navarro J., Coll M., Aguzzi J., Cardona L. and Sáez-Liante R. (2015) Feeding ecology and trophic position of three sympatric demersal chondrichthyans in the northwestern Mediterranean. Marine Ecology Progress Series 524, 255-268.

Anastasopoulou A., Mytilineou C., Lefkaditou E., Dokos J., Smith C. J., Siapatis A., Bekas P. and Papadopoulou K. N. (2013) Diet and feeding strategy of blackmouth catshark Galeus melastomus. Journal of fish biology 83,6, 1637-1655.

Barría C., Navarro J., Coll M., Fernandez-Arcaya U. and Sáez-Liante, R. (2015) Morphological parameters of abundant and threatened chondrichthyans of the northwestern Mediterranean Sea. Journal of Applied Ichthyology 31, 114-119.

Barría C., Navarro J. and Coll M. (2017) Trophic habits of an abundant shark in the northwestern Mediterranean Sea using an isotopic non-lethal approach. Estuarine, Coastal and Shelf Sciencie https://doi.org/10.1016/j.ecss.2017.08.021 
Baum J. K. and Worm B. (2009) Cascading top-down effects of changing oceanic predator abundances. Journal of Animal Ecology 78, 699-714.

Bello G. (1997) Cephalopods from the stomach contents of demersal chondrichthyans caught in the Adriatic Sea. Vie Milieu 47, 221-227.

Bradai M. N., Saidi B. and Enajjar S. (2012) Elasmobranchs of the Mediterranean and Black Sea: Status, Ecology and Biology: A Bibiliographic Analysis. Food and Agriculture Organisation of the United Nations.

Capapé C. (1974) Contribution a la biologie des Scyliorhinidae des cotes Tunisiennes. Annales de l'Institut Michel Pacha 7, 13-29.

Compagno L. J.V. (1984) FAO Species Catalogue. Vol. 4. Sharks of the world. An annotated and illustrated catalogue of shark species known to date. Part 2 - Carcharhiniformes, FAO Fish. Synop. 125, 4/2, 251-655. Rome: FAO, ISBN 92-5-101383-7.

Cortés E. (1997) A critical review of methods of studying fish feeding based on analysis of stomach contents: application to elasmobranch fishes. Canadian Journal of Fisheries and Aquatic Sciences 54, 726-738.

Cortés E. (1999) Standardized diet compositions and trophic levels of sharks. ICES Journal of Marine Science 56, 707-717.

Çakır D. T., Koç H. T. and Başusta A. (2006) Length-weigth Relationship of 24 fish species from Edremit Bay, Aegean Sea. e-Journal of New World Sciences Academy Natural and Applied Sciences 3, 47-51.

De Niro M. J. and Epstein S. (1981) Isotopic composition of cellulose from aquatic organisms. Geochimica et Cosmochimica Acta 45, 1885-1894.

Dulvy N.K., Fowler S.L., Musick J.A., Cavanagh R.D., P.M., Kyne L.R., Harrison J.K., Carlson L.N.K., Davidson S.V., F.M.P., Francis C.M., Pollock C.A., Simpfendorfer G. H., Burgess K.E., Carpenter L. J. V., Compagno D.A., Ebert C., Gibson M. R., Heupel 

Extinction risk and conservation of the world's sharks and rays. eLife 3, 1-83.

Ellis J. R., Pawson M. G. and Shackley S. E. (1996) The comparative feeding ecology of six species of shark and four species of ray (Elasmobranchii) in the North-East Atlantic. Journal of the Marine Biological Association of the United Kingdom 76, 89-106.

Eronat E.G. (2012) Orta Ege Denizi'ndeki chondrichthyes (kıkırdaklı balık) türlerinin beslenme özelliklerinin belirlenmesi, Science Institute of Ege University. Master Thesis 58 pp. [In Turkish]

Estrada J. A., Rice A. N., Lutcavage M. E. and Skomal G. B. (2003) Predicting trophic position in sharks of the northwest Atlantic Ocean using stable isotope analysis. Journal of the Marine Biological Association of the United Kingdom 83, 1347-1350.

Fanelli E., Rey J., Torre, P. and Gil de Sola L. (2009) Feeding habits of blackmouth catshark Galeus melastomus Rafinesque, 1810 and velvet belly lantern shark Etmopterus spinax (Linnaeus, 1758) in the western Mediterranean. Journal of Applied Ichthyology 25(s1), 8393.

Ferretti F., Osio,G.C., Jenkins C.J., Rosenberg A.A. and Lotze H.K. (2013) Long-term change in a meso-predator community in response to prolonged and heterogeneous human

Filiz H. and Taskavak E. (2006) Sexual dimorphism in the head, mouth, and body morphology of the smallspotted catshark, Scyliorhinus canicula (Linnaeus, 1758)(Chondrichthyes: Scyliorhinidae) from Turkey. Acta Adriatica 47, 37-47.

Filiz H. (2009) Diet composition of smooth-hound, Mustelus mustelus (Linnaeus, 1758), in Aegean Sea, Turkey. Belgium Journal of Zoology 139, 81-84 
Güreşen A., Okudan E. Ş., Dural B. and Aysel V. (2015) An Updated Checklist of Marine Flora on The Continental Shelf of Gökçeada Island (Northern Aegean Sea, Turkey). Aquaculture Engineering and Fisheries Research, 171.

Fry B. (2007) Stable isotope ecology. Springer Science and Business Media, New York, USA, ISBN-10: 0-387-30513-0.

Heithaus M.R., Vaudo J.J., Kreicker S., Layman C.A., Krützen M., Burkholder D.A., Gastrich K., Bessey C., Sarabia R. and Cameron K. (2013) Apparent resource partitioning and trophic structure of large-bodied marine predators in a relatively pristine seagrass ecosystem. Marine Ecology Progress Series 481, 225-237

Hussey N. E., Brush J., McCarthy I. D. And Fisk A. T. (2010) $\delta^{15} \mathrm{~N}$ and $\delta^{13} \mathrm{C}$ diet-tissue discrimination factors for large sharks under semi-controlled conditions. Comparative Biochemistry and Physiology Part A: Molecular and Integrative Physiology 155,4, 445-453.

Hyslop E. J. (1980) Stomach contents analysis - a review of methods and their application. Journal of fish biology 17, 411-429.

IUCN, The IUCN Red List of Threatened Species. Version 2015.3. $<$ http://www.iucnredlist.org>. Downloaded on 01 February 2018.

Jackson A.L., Inger R., Parnell A.C. and Bearhop, S. (2011) Comparing isotopic niche widths among and within communities: SIBER-Stable isotope Bayesian ellipses in R. Journal of Animal Ecology 80, 595-602.

Jardas I. (1972) Supplement to the knowledge of ecology of some Adriatic cartilaginous fishes (Chondrichthyes) with special reference to their nutrition. Acta Adriatica 14, 3-60.

Jardas I., Šantić M., Nerlović V. and Pallaoro A. (2007) Diet of the smooth-hound Mustelus mustelus (Chondrichthyes: Triakidae) in the eastern Adriatic Sea. Cybium 31, 459-464.

Jennings S., Reñones O., Morales-Nin B., Polunin N. V. C. Moranta J. and Coll, J. (1997) Spatial variation in the $15 \mathrm{~N}$ and $13 \mathrm{C}$ stable isotope composition of plants, invertebrates and 
fishes on Mediterranean reefs: implications for the study of trophic pathways. Marine Ecology Progress Series 146, 109-116.

Kabasakal H. (2001) Preliminary data on the feeding ecology of some selachians from NorthEastern Aegean Sea. Acta Adriatica 42, 15-24.

Kabasakal H. (2002a) Elasmobranch species of the seas of Turkey. Annales Series Historia Naturalis 12, 15-22.

Kabasakal H. (2002b) Cephalopods in the stomach contents of four Elasmobranch species from the northern Aegean Sea. Acta Adriatica 43,17-24.

Kabasakal H. (2002c) Stomach contents of the longnose spurdog, Squalus blainvillei (Risso, 1826) from the north-eastern Aegean Sea. Annales Series Historia Naturalis 12, 173-176.

Karachle P. K. and Stergiou K. I. (2008) The effect of season and sex on trophic levels of marine fishes. Journal of Fish Biology 72, 1463-1487.

Karachle P. and Stergiou K. I. (2010) Food and feeding habits of nine elasmobranch species in the Aegean Sea. Rapports de la Commission Internationale pour L'Exploration Scientifique de la Mer Mediterranee 39, 553.

Kim S. L. and Koch P. L. (2012) Methods to collect, preserve, and prepare elasmobranch tissues for stable isotope analysis. Environmental Biology Fishes 95, 53-63.

Kim S. L., del Rio C. M., Casper D. and Koch P., L. (2012) Isotopic incorporation rates for shark tissues from a long-term captive feeding study. Journal of Experimental Biology 215, 2495-2500.

Kousteni V., Karachle P. K. and Megalofonou P. (2017a) Diet of the small-spotted catshark Scyliorhinus canicula in the Aegean Sea (eastern Mediterranean). Marine Biology Research 13, 161-173. 
Kousteni V., Karachle P. K. and Megalofonou P. (2017b) Diet and trophic level of the longnose spurdog Squalus blainville (Risso, 1826) in the deep waters of the Aegean Sea. Deep Sea Research Part I: Oceanographic Research Papers, 124, 93-102.

Layman C.A., Araujo M.S., Boucek R., Hammerschlag-Peyer C.M., Harrison E., Jud, Z.R., Matich P., Rosenblatt A.E., Vaudo J.J., Yeager L.A., Post D.M., Bearhop S. (2012) Applying stable isotopes to examine food-web structure: an overview of analytical tools. Biological Review of Cambrige Philosophy Society 87, 545-562.

Macpherson E. (1981) Resource partitioning in a Mediterranean demersal fish community. Marine Ecology Progress Series 4, 183-193.

MacNeil M., Skomal G. and Fisk A. (2005) Stable isotopes from multiple tissues reveal diet switching in sharks. Marine Ecology Progress Series 302,199-206

Machias A., Giannoulaki M., Somarakis S. and Siapatis A. (2007) Small pelagic fish. In: Papaconstantinou C., Zenetos A., Vassilopoulou V., Tserpes, G. (Eds.), State of Hellenic Fisheries. Hellenic Center for Marine Research Publications, Athens, pp. 192e207

Mnasri, N., El Kamel, O., Boumaiza, M., Reynaud, C., Capape, C. (2012). Food and feeding habits of the small-spotted catshark, Scyliorhinus canicula (Chondrichthyes: Scyliorhinidae) from the northern coast of Tunisia (central Mediterraneean). Cahiers de biologie marine, 53(1), 139-150.

Navia A.F., Mejía-Falla P.A., López-García J., Giraldo A. and Cruz-Escalona V.H. (2017) How many trophic roles can elasmobranchs play in a marine tropical network? Marine and Freshwater Research 68: 12

Olaso I., Velasco F. and Pérez N. (1998) Importance of discarded blue whiting (Micromesistius poutassou) in the diet of lesser spotted dogfish (Scyliorhinus canicula) in the Cantabrian Sea. ICES Journal of Marine Science 55, 331-341 
Olin J. A., Hussey N. E., Grgicak-Mannion A., Fritts M. W., Wintner S. P., Fisk A. T. (2013) Variable $\delta 15 \mathrm{~N}$ diet-tissue discrimination factors among sharks: implications for trophic position, diet and food web models. PloS one, 8,10.

Öztürk B. (2009) Marine protected areas in the high seas of the Aegean and Eastern Mediterranean Seas, some proposals. Journal of Black Sea/Mediterranean Environment 15, 69-82.

Özcan E. İ. and Başusta N. (2015) Kuzeydoğu Akdeniz Bölgesi’nde yaşayan Benekli Kedibalığı, (Scyliorhinus canicula (Linnaeus, 1758))'nın mide içeriği. Su Ürünleri Dergisi 32, 193-195. [In Turkish]

Özcan E. İ. and Başusta N. (2016) Kuzeydoğu Akdeniz Bölgesinde Yaşayan Adi Köpekbalığ1, Mustelus mustelus (Linnaeus, 1758)'un Mide İçeriği. Fırat Üniversitesi Fen Bilimleri Dergisi, 28, 7-12. [In Turkish]

Özütemiz Ş., Kaya M. and Özaydın O. (2009) Sığacık Körfezi’nde (Ege Denizi) Bulunan İki Tür Köpekbalığının [Galeus melastomus Rafinesque, 1810 ve Squalus blainvillei (Risso, 1826)] Boy-Ağırlık İlişkisi ve Beslenme Özellikleri Üzerine Bir Ön Çalışma. Ege Üniversitesi Su Ürünleri Dergisi, 26, 211-217. [In Turkish]

Pauly D., Froese R., Sa-a P. S., Palomares M. L., Christensen V. and Rius J. (2000) TrophLab manual. ICLARM, Manila.

Peterson B. J., Fry B. (1987) Stable isotopes in ecosystem studies. Annual review of ecology and systematics $1,293-320$.

Pethiakis G., Tsiaras K., Triantafyllou G., Kalaroni S. and Pollani, A. (2014) Sensitivity of the N. Aegean Sea ecosystem to Black Sea Water inputs. Mediterranean Marine Science 15: $790-804$.

Pianka E. R. (2000) Evolutionary ecology. Harper Collins. 
Saidi B., Enajjar S., Bradai M. N., Bouain A. (2009) Diet composition of smooth-hound shark, Mustelus mustelus (Linnaeus, 1758), in the Gulf of Gabès, southern Tunisia. Journal of Applied Ichthyology 25(s1), 113-118.

Šantić M., Rađa B. and Pallaoro A. (2012) Feeding habits of small-spotted catshark (Scyliorhinus canicula Linnaeus, 1758) from the eastern central Adriatic Sea. Marine Biology Research 8,1003-1011.

Shiffman D., Gallagher A., Boyle M., Hammerschlag-Peyer C. and Hammerschlag N. (2012) Stable isotope analysis as a tool for elasmobranch conservation research: a primer for non-specialists. Marine and Freshwater Research 63, 635-643.

Stergiou K.I., Christou E.D., Georgopoulos D., Zenetos A., Souvermesoglou C. (1997) Hellenic Seas: physics, chemistry, biology and fisheries. Oceanography and Marine Biology an Annual Review 35, 415e538

Stergiou K. I. and Karpouzi V. S. (2001) Feeding habits and trophic levels of Mediterranean fish. Reviews in fish biology and fisheries 11, 217-254.

Valls M., Quetglas A., Ordines F. and Moranta J. (2011) Feeding ecology of demersal elasmobranchs from the shelf and slope off the Balearic Sea (western Mediterranean). Scientia Marina 75, 633-639.

Vaudo J. J. and Heithaus M. R. (2011). Dietary niche overlap in a nearshore elasmobranch mesopredator community. Marine Ecology Progress Series 425, 247-260.

White W. T., Platell M. E. and Potter I. C. (2004) Comparisons between the diets of four abundant species of elasmobranchs in a subtropical embayment: implications for resource partitioning. Marine Biology 144, 439-448.

Yığın C. Ç., İşmen A., Umur Ö. N. A. L. and Arslan M. (2015) Cartilaginous fishes and fisheries in the Aegean Sea. The Aegean Sea, 286. 
474 Zanden M. and Rasmussen J.B. (2001) Variation in $\delta^{15} \mathrm{~N}$ and $\delta^{13} \mathrm{C}$ trophic fractionation:

475 implications for aquatic food web studies. Limnology and Oceanography 46, 2061-2066.

476

477

478 


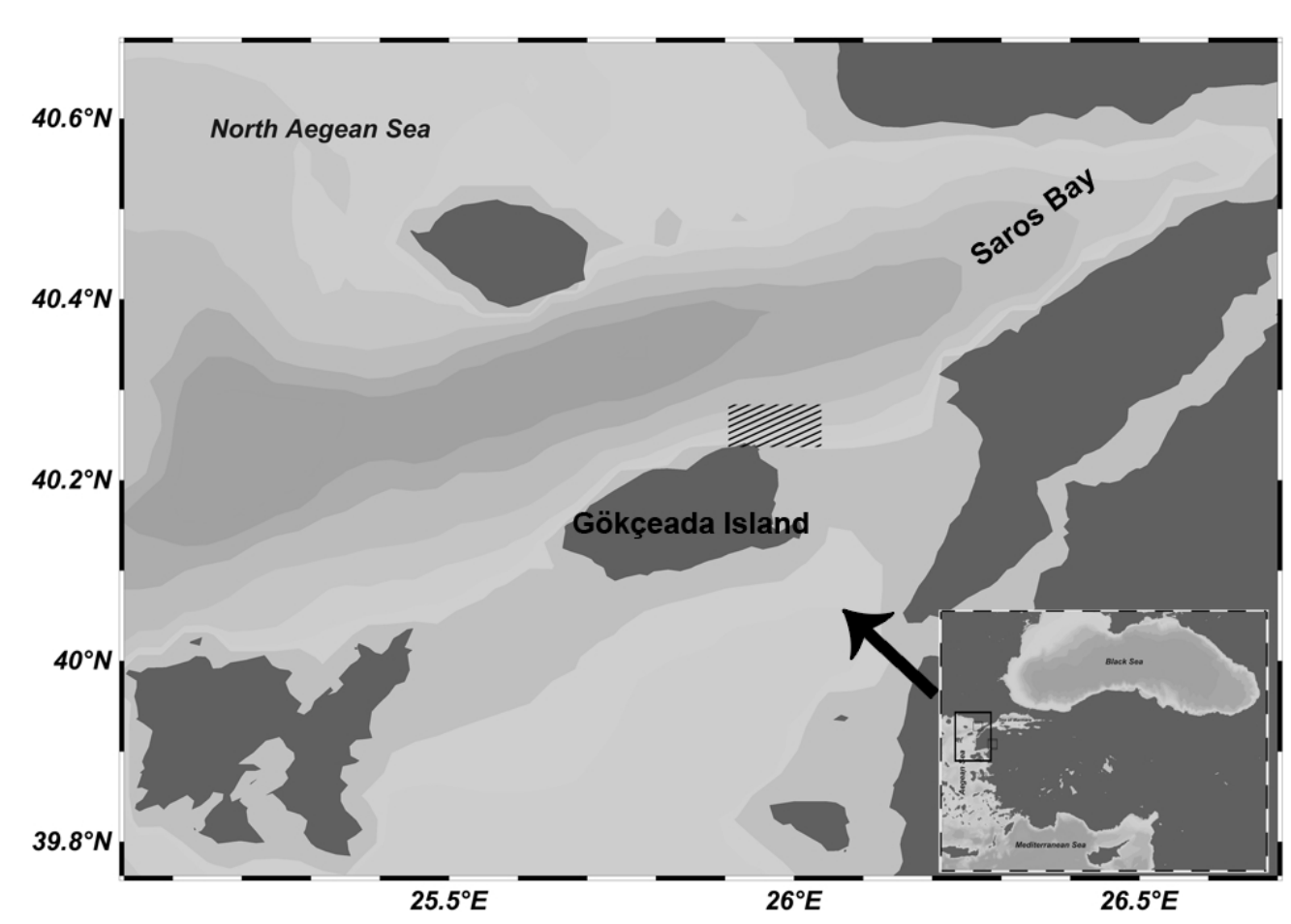

Figure 1. Study area (Gökçeada Island, North Aegean Sea) 
Table 1. Stomach content results of blackmouth catshark Galeus melastomus, common smoothhound Mustelus mustelus, longnose spurdog Squalus blainville, small-spotted catshark Scyliorhinus canicula and nursehound $S$. stellaris collected in the North Aegean Sea. N=sample size; Total length of individuals; mean and standar deviation of fullness index; $V=$ vacuity index; $\mathrm{FO} \%=$ Frequency of occurrence and $\mathrm{W} \%=$ weight.

\begin{tabular}{|c|c|c|c|c|c|c|c|c|c|c|}
\hline & \multicolumn{2}{|c|}{$\begin{array}{c}\text { Blackmouth } \\
\text { catshark }\end{array}$} & \multicolumn{2}{|c|}{$\begin{array}{c}\text { Common } \\
\text { smoothhound }\end{array}$} & \multicolumn{2}{|c|}{$\begin{array}{c}\text { Small-spotted } \\
\text { catshark }\end{array}$} & \multicolumn{2}{|c|}{ Nursehound } & \multicolumn{2}{|c|}{$\begin{array}{c}\text { Longnose } \\
\text { spurdog }\end{array}$} \\
\hline $\mathrm{N}$ & \multicolumn{2}{|c|}{26} & \multicolumn{2}{|c|}{8} & \multicolumn{2}{|c|}{14} & \multicolumn{2}{|c|}{64} & \multicolumn{2}{|c|}{12} \\
\hline Total Length (mm) & \multicolumn{2}{|c|}{$227 \pm 35.6$} & \multicolumn{2}{|c|}{$911.5 \pm 11.2$} & \multicolumn{2}{|c|}{$299 \pm 37.8$} & \multicolumn{2}{|c|}{$478.71 \pm 193.2$} & \multicolumn{2}{|c|}{$591 \pm 79.3$} \\
\hline Fullnes index & \multicolumn{2}{|c|}{$64.64 \pm 20.48$} & \multicolumn{2}{|c|}{$76.55 \pm 4.56$} & \multicolumn{2}{|c|}{$38.51 \pm 18.6$} & \multicolumn{2}{|c|}{$57.87 \pm 12.96$} & \multicolumn{2}{|c|}{$46.82 \pm 30.35$} \\
\hline$V(\%)$ & \multicolumn{2}{|c|}{7} & \multicolumn{2}{|c|}{0} & \multicolumn{2}{|c|}{8} & \multicolumn{2}{|c|}{3} & \multicolumn{2}{|c|}{14} \\
\hline Trophic Level & \multicolumn{2}{|c|}{4.41} & \multicolumn{2}{|c|}{4.35} & \multicolumn{2}{|c|}{4.22} & \multicolumn{2}{|c|}{3.99} & \multicolumn{2}{|c|}{4.17} \\
\hline Prey/Metric & FO\% & W\% & FO\% & W\% & FO\% & W\% & FO\% & W\% & FO\% & W\% \\
\hline \multicolumn{11}{|l|}{ ANNALIDA } \\
\hline POLYCHAETES & & & & & 4.7 & 3.2 & & & & \\
\hline CRUSTACEANS & 12.5 & 10.28 & 87.5 & 16.9 & 25.6 & 25.9 & 28.6 & 33.5 & 24.2 & 37 \\
\hline Liocarcinus depurator & & & 25 & 7.7 & & & & & & \\
\hline Munida intermedia & & & 12.5 & 4.02 & & & & & & \\
\hline Parapeneus longirostris & 12.5 & 10.28 & & & 12.5 & 17.3 & & & 4.26 & 16.31 \\
\hline Unidentified Crustaceans & & & 87.5 & 5 & 25.6 & 8.6 & & & & \\
\hline CEPHALOPODS & 18.75 & 33.9 & 25 & 53.1 & 25.6 & 27 & 42.9 & 50.6 & 18.2 & 14.6 \\
\hline Illex coidetti & & & 25 & 53.1 & & & & & & \\
\hline Loligo vulgaris & 4.76 & 12.7 & & & & & & & & \\
\hline Unidentified Cephalapods & 14.28 & 17.6 & & & & & & & & \\
\hline TELEOSTS & 62.5 & 55.7 & 37.5 & 30 & 41.9 & 43.8 & 28.6 & 15.9 & 54.5 & 48.4 \\
\hline Engraulis encrasicolus & & & 25 & 18.1 & & & & & 8.3 & 4.13 \\
\hline Unidentfied Teleost & 62.5 & 55.7 & 25 & 11.9 & 41.9 & 43.8 & 28.6 & 15.9 & 46.2 & 43.9 \\
\hline DIGESTED MATERIAL & & 12.6 & & 5.9 & & 36.8 & & 47.5 & & 17.8 \\
\hline
\end{tabular}




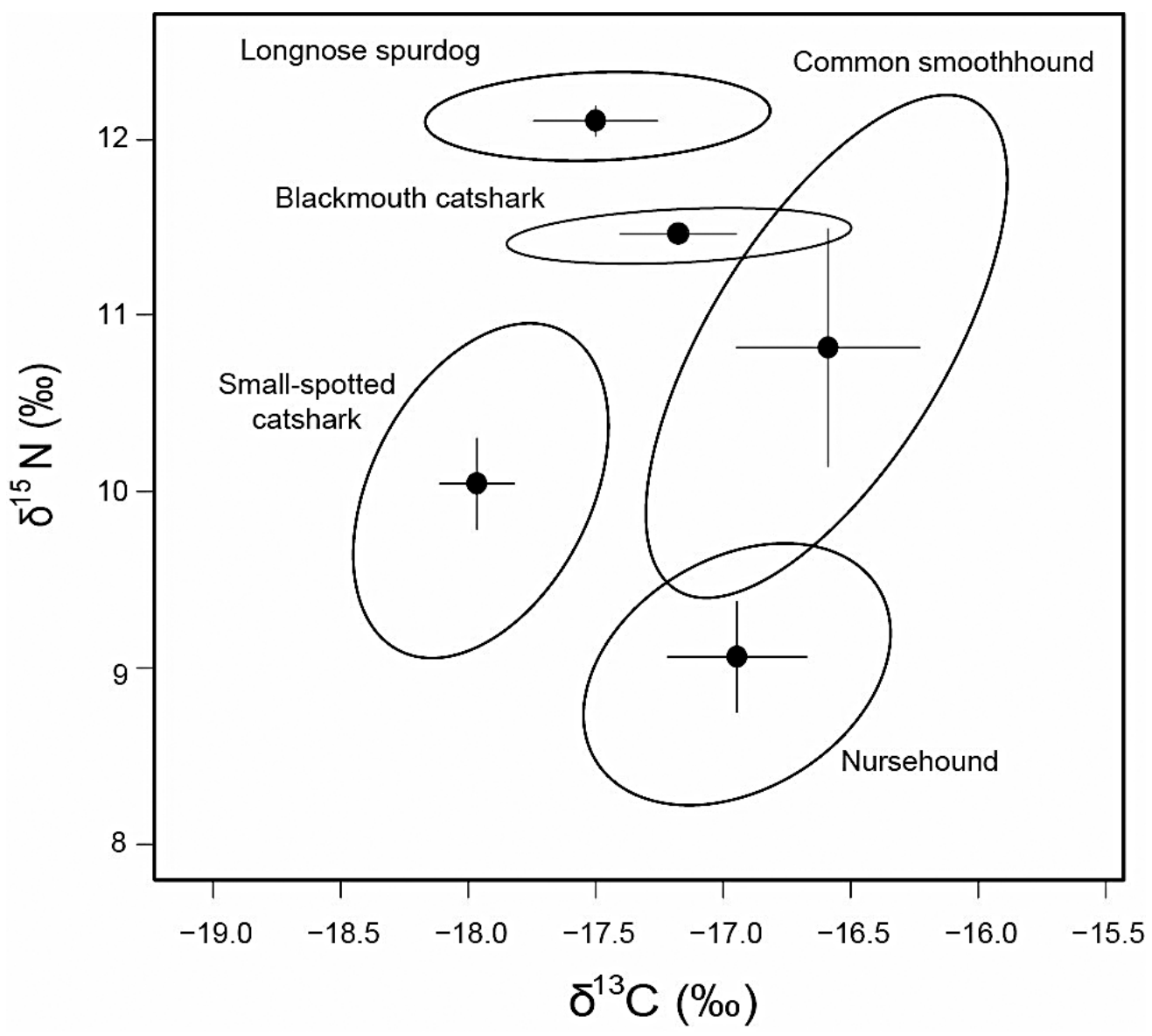

Figure 2. Isotopic Bayesian Standard Ellipse Areas (SEAc) and Mean ( \pm standard error) of $\delta 13 \mathrm{C}$ and $\delta 15 \mathrm{~N}$ values of blackmouth catshark Galeus melastomus, common smoothhound Mustelus mustelus, longnose spurdog Squalus blainville, small-spotted catshark Scyliorhinus canicula and nursehound S. stellaris from the north Aegean Sea

$166 \times 148 \mathrm{~mm}(150 \times 150 \mathrm{DPI})$ 
Table 2. Mean and standard deviation of $\delta^{13} \mathrm{C}, \delta^{15} \mathrm{~N}$ and trophic level $\left(\mathrm{TP}_{\mathrm{SIA}}\right)$ estimated with $\delta^{15} \mathrm{~N}$ of blackmouth catshark Galeus melastomus, common smoothhound Mustelus mustelus, longnose spurdog Squalus blainville, small-spotted catshark Scyliorhinus canicula and nursehound S. stellaris

\begin{tabular}{ccccccc}
\hline Species & $\mathrm{n}$ & Sampling month & Depth range $(\mathrm{m})$ & $\delta^{13} \mathrm{C}(\%)$ & $\delta^{15} \mathrm{~N}(\%)$ & $\mathrm{TP}_{\text {SIA }}$ \\
\hline Blackmouth catshark & 9 & February 2015 & $235-450$ & $-17.17 \pm 0.63$ & $11.45 \pm 0,15$ & $4.54 \pm 0.07$ \\
& & April 2015 & $180-250$ & $-16.60 \pm 0.61$ & $10.82 \pm 1.23$ & $4.23 \pm 0.63$ \\
Common smouthhound & 4 & & $150-315$ & $-17.49 \pm 0.63$ & $12.12 \pm 0.24$ & $4.89 \pm 0.12$ \\
Longnose spurdog & 8 & September 2015 & & & & \\
Small-spotted catshark & 12 & September 2015 & $38-275$ & $-17.95 \pm 0.48$ & $10.01 \pm 0.91$ & $3.81 \pm 0.46$ \\
Nursehound & 5 & April 2015 & $33-150$ & $-16.95 \pm 0.54$ & $8.96 \pm 0.66$ & $3.27 \pm 0.34$ \\
\hline
\end{tabular}


Table 3. Main prey groups in diet of blackmouth catshark Galeus melastomus, common smoothhound Mustelus mustelus, longnose spurdog Squalus blainville, small-spotted catshark Scyliorhinus canicula and nursehound $S$. stellaris from Mediterranean Sea

\begin{tabular}{|c|c|c|c|}
\hline Species & Region & Main prey group & Reference \\
\hline Blackmouth catshark & Aegean Sea & Cephalopods, Teleosts & Present study \\
\hline Blackmouth catshark & Western Mediterranean & Cephalopods & Aldo-Puigserver et al., 2015 \\
\hline Blackmouth catshark & Ionian Sea & Cephalopods, Teleosts, Crustaceans & Anastasopoulou et al., 2013 \\
\hline Blackmouth catshark & Aegean Sea & Crustaceans, Teleosts & Özütemiz et al., 2009 \\
\hline Blackmouth catshark & Adriatic Sea & Cephalapods & Bello, 1997 \\
\hline Blackmouth catshark & Western Mediterranean & Crustaceans, Cephalopods & Fanelli et al., 2009 \\
\hline Blackmouth catshark & Western Mediterranean & Crustaceans, Teleosts, Cephalopods & Valls et al., 2011 \\
\hline Common smoothhound & Aegean Sea & Crustaceans, Cephalopods, Teleosts & Present study \\
\hline Common smoothhound & Levantine Sea & Crustaceans, Teleosts & Özcan \& Basusta, 2016 \\
\hline Common smoothhound & Aegean Sea & Crustaceans, Teleosts & Eronat, 2012 \\
\hline Common smoothhound & Central Mediterranean & Teleosts, Cephalopods & Saidi et al., 2009 \\
\hline Common smoothhound & Aegean Sea & Crustaceans, Teleosts & Filiz, 2009 \\
\hline Common smoothhound & Aegean Sea & Cephalapods & Kabasakal, 2002b \\
\hline Common smoothhound & Adriatic Sea & Teleosts, Crustaceans & Jardas et al., 2007 \\
\hline Small-spotted catshark & Aegean Sea & Crustaceans, Teleosts, Cephalopods & Present study \\
\hline Small-spotted catshark & Aegean Sea & Crustaceans, Teleosts, Cephalopods & Kousteni et al., 2017a \\
\hline Small-spotted catshark & Levantine Sea & Crustaceans, Teleosts & Özcan \& Basusta, 2015 \\
\hline Small-spotted catshark & Aegean Sea & Crustaceans & Eronat, 2012 \\
\hline Small-spotted catshark & Adriatic Sea & Crustaceans, Teleosts & Santic et al., 2012 \\
\hline Small-spotted catshark & Central Mediterranean Sea & Crustaceans, Teleosts & Mnasri et al., 2012 \\
\hline Small-spotted catshark & Adriatic Sea & Cephalopods & Bello, 1997 \\
\hline Small-spotted catshark & Aegean Sea & Crustaceans, Teleosts & Filiz \& Taşkavak, 2006 \\
\hline Small-spotted catshark & Aegean Sea & Crustaceans, Teleosts & Kabasakal, 2001 \\
\hline Small-spotted catshark & Aegean Sea & Crustaceans, Teleosts & Cihangir et al., 1997 \\
\hline Small-spotted catshark & Central Mediterranean & Crustaceans, Teleosts & Capape, 1974 \\
\hline Small-spotted catshark & Western Mediterranean & Crustaceans & Valls et al., 2011 \\
\hline Small-spotted catshark & Western Mediterranean & Crustaceans & Barría et al., 2018 \\
\hline Nursehound & Northern Aegean Sea & Cephalopods, Crustaceans, Teleosts & Present study \\
\hline Nursehound & Aegean Sea & Teleosts & Eronat, 2012 \\
\hline Longnose spurdog & Aegean Sea & Teleosts, Crustaceans & Present study \\
\hline Longnose spurdog & Aegean Sea & Cephalopods, Teleosts & Kousteni et al., 2017b \\
\hline Longnose spurdog & Aegean Sea & Crustaceans, Teleosts & Özütemiz et al., 2009 \\
\hline Longnose spurdog & Aegean Sea & Cephalopods & Kabasakal, 2002b \\
\hline
\end{tabular}

